\title{
Photodynamic Therapies in the Treatment of Periodontal Disease
}

\author{
Fuad Alaijah*, Riman Nasher and Norbert Gutknecht \\ Al Asmarya University, Libya \\ *Corresponding author: Fuad Alaijah, Faculty of Dentistry, Al Asmarya University, Zliten, Libya
}

Submission: 監 May 22, 2018; Published: 監 June 11, 2018

\begin{abstract}
Objectives: Many studies in the literature address the effect of photodynamic therapy in the management of pathologies related to periodontal tissue. Due to the lack of standardized information and the absence of a consensus, this review presents the effect of photodynamic therapy (PDT) on microorganisms involved in periodontal diseases.
\end{abstract}

Materials and methods: The literature and original research articles were used to investigate the effect of Photodynamic therapy (PDT) in periodontal diseases. Online MEDLINE/PubMed database were the main source. Google scholar were used a second search date base for online resources where access was not approachable through MEDLINE. Access date were between 01/9/2007and 30/01/2017. The research was confined to English Language literature. The literature search retrieved references on antimicrobial photodynamic therapy.

Results: In total, 38 photodynamic relevant articles were included in the review, comprising work completed on a variety of cell types and places. Although results consistently demonstrated the potential of laser irradiation to affect antimicrobial photodynamic therapy in a wavelength and dosagedependent manner, the relevance of other key irradiation parameters, such as irradiance, to such effects remained unclear

Conclusion: The in vivo and in vitro studies present in the literature, indicate that aPDT may potentially become successful. In addition, infectious procedure associated with conventional therapy can be successful in the management of periodontal disease.

Keywords: Photodynamic treatment; Antimicrobial photodynamic therapy (aPDT); Periodontal disease

Abbreviations: PDT: Photodynamic Therapy; TD: Treponema Denticola; CAL: Clinical Attachment Level; AP: Aggressive Periodontitis; GBI: Gingival Bleeding Index; ER: Erythrosine; MB: Methylene Blue; PPD: Probing Pocket Depth; TF: Tannerella Forsythia

\section{Introduction}

Periodontal disease is defined as an "inflammatory disease of the supporting tissues of the teeth caused by specific microorganisms, which lead to progressive destruction of the periodontal membrane and alveolar bone, with formation of periodontal pockets and gingival recession"[1]. Periodontal disease extent from simple gum inflammation to an aggressive gum disease that results in damage to supporting structure, periodontal ligament and bone which are considered the main support to the teeth and in the worst cases teeth could be missing [2]. When gingivitis is not treated, it could be deteriorated to 'periodontitis' which means inflammation around the tooth [3].

Three clinical parameters are typically recorded in periodontal disease [4]

a) Bleeding on probing, this reflects the presence of an inflammatory infiltrate in gingival tissues with loss of integrity of the sulcular epithelium.

b) Clinical attachment level, which reflects the amount of periodontal tissue loss [4]. c) Pathological deepening of the periodontal pocket more than $3 \mathrm{~mm}$, which describes the deepening of the gingival sulcus where the dental plaque biofilm can propagate apically along the root surface [5].

The application of photosensitive dyes into pockets and their activation by light promote killing of periodontal pathogens. Outcomes of clinical studies in subjects with chronic periodontitis show beneficial results of PDT on the reduction in gingival inflammation [6]. Photodynamic treatment is a technique combining laser energy with a photosensitizer to product singlet oxygen molecules and free radicals to break down targeted cells [7]. The process of a PDT requires the presence of a photosensitizing drug in addition to an oxygen agent in the target tissue (microorganisms). The interaction between the photosensitizer and microorganisms occurs within a few minutes, and this period (incubation or preirradiation time) is taken into consideration before laser irradiation to ensure that the dye is absorbed by the bacteria $[8,9]$. The clinical application of PDT in the treatment of periodontitis has been tested for nonsurgical management of aggressive forms 
of the disease. In previous work, PDT and nonsurgical periodontal treatment showed similar clinical outcomes after 3 months, and both led to statistically significant reductions in tumor necrosis factor-a (TNF-a) and receptor activation of nuclear factor (RANKL) Levels 30 days following treatment [7]. Moreover, PDT can destroy the vasculature surrounding tumor cells, and activates immunological responses against them [10]. PDT is relatively non-invasive, and treatments can be repeated without induction of resistance [11].

One of the potential alternative approaches to periodontal therapy is the association of the conventional treatment with antimicrobial Photodynamic therapy (aPDT), a first report on the comparison of conventional debridement with or without the adjunctive use of antimicrobial Photodynamic therapy (aPDT) in the treatment of chronic periodontitis revealed higher improvements of clinical parameters in the aPDT group [8].

An ideal photosensitizer for PDT should have specific properties.

i. The absorption band should be on wavelength longer than $600 \mathrm{~nm}$ so that it is easily distinguished from biological stances, such as hemoglobin.

ii. The molecular extinction coefficient of the absorption wave length should be large and produce sufficient singlet oxygen upon light-induced excitation.

iii. The substance should have a high affinity for the target, distribute homogeneously, and be rapidly excreted from normal tissue [12].

\section{Objectives}

The aspect of this research topic is to conduct an extensive literature review on the topics discussing the effect of Photodynamic therapy (PDT) as an adjuvant therapy to the classic periodontal treatment.

\section{Research query}

How does the Photodynamic therapy (PDT) affect the microorganisms involved in periodontal diseases?

\section{Materials and Methods}

Available literature and original research articles were used to investigate the effect of Photodynamic therapy (PDT) in periodontal diseases. PubMed database was the main source. Google scholar was used a second search date base for online resources where access was not approachable through MEDLINE. Access date was between 01/9/2007 and 30/01/2017. The research was confined to English Language literature. The following keywords were used: "Photodynamic therapy (PDT), Antimicrobial Photodynamic therapy (aPDT), periodontal disease".

\section{Inclusion criteria}

a) All human studies (in vivo and in vitro studies).

b) Determine the following treatment parameters: power, power density, energy, energy density, frequency of treatment, beam and dose expressed in $\left(\mathrm{J} / \mathrm{cm}^{2}\right)$.

c) Special condition during the treatment, for example, diabetic ulcers.

\section{Exclusion criteria}
a) Systemic review
b) Literature review
c) Histological studies
d) Animals studies

\section{Search outcomes}

As seen in Figure 11000 articles were reviewed and were divided based on topic. The outcome after the inclusion and exclusion criteria was 38 articles regarding to Photodynamic therapy (PDT) (Figure 2).

\section{Results}

The results of the 38 papers regarding PDT that are reviewed and summarized in Table 1.

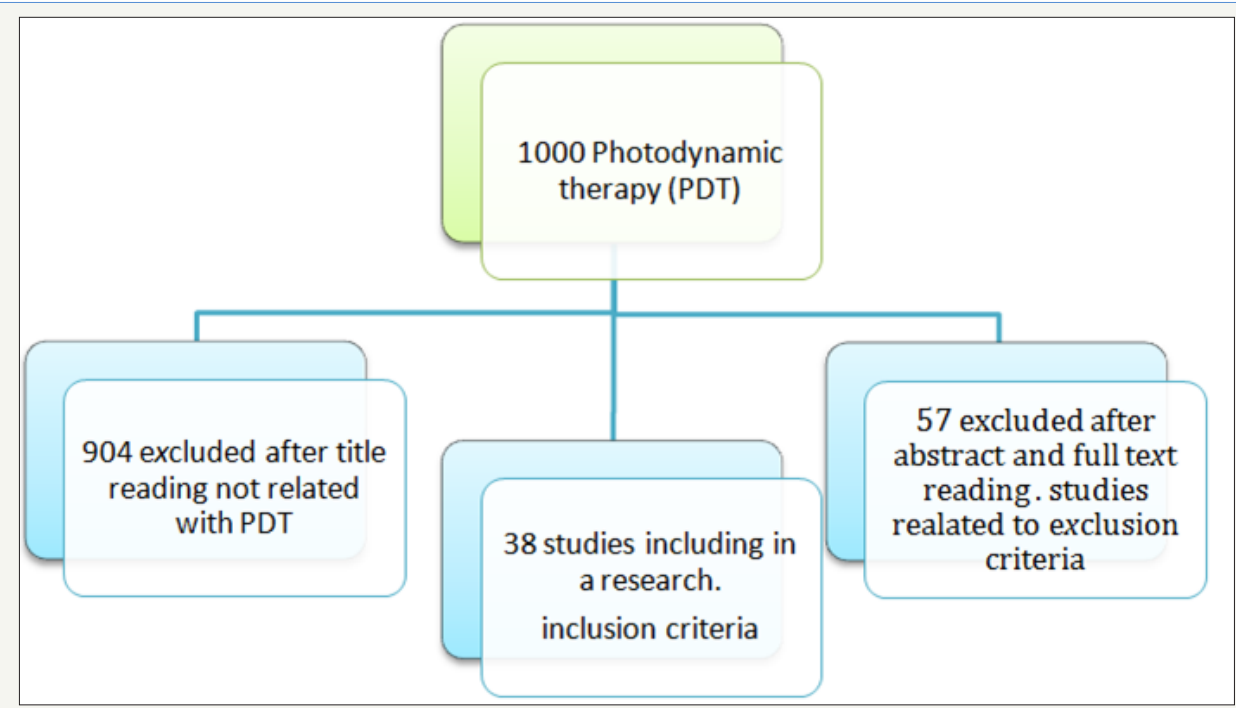

Figure 1: Search Outcomes. 


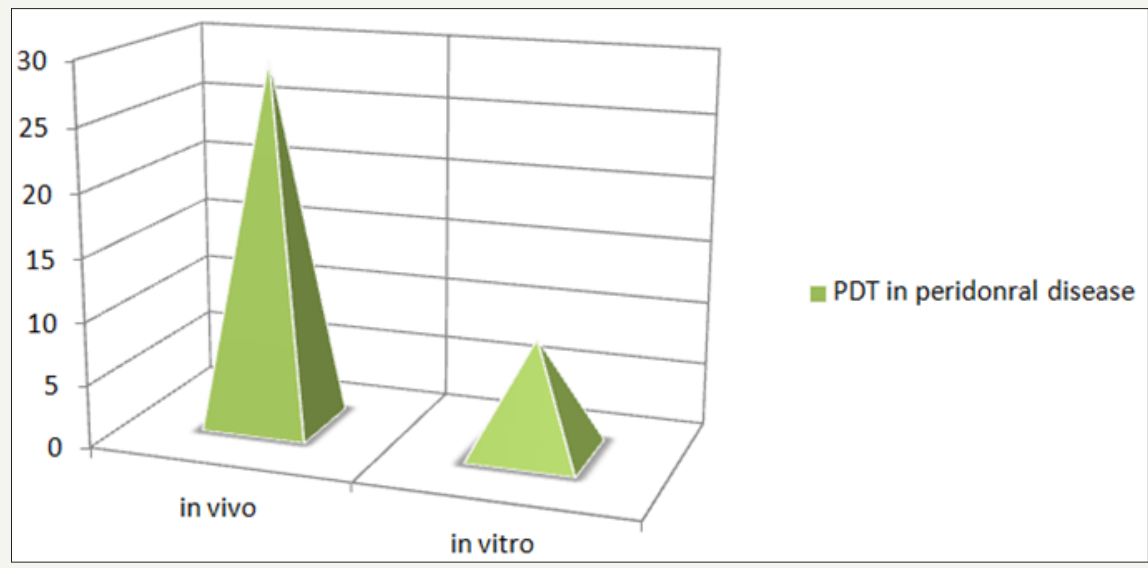

Figure 2: Demonstrate how many articles included in this review regarding to PDT.

Table 1: Laser irradiation conditions and results observed in vitro and in vivo Antimicrobial Photodynamic therapy.

\begin{tabular}{|c|c|c|c|c|c|c|c|c|}
\hline Study & Reference & $\begin{array}{l}\text { Laser and } \\
\text { Wavelength } \\
\text { (nm) }\end{array}$ & Photosensitization & $\begin{array}{l}\text { Dose } \\
\mathrm{J} / \mathrm{cm}^{2}\end{array}$ & $\begin{array}{c}\text { Power } \\
\text { Density } \\
\mathrm{mW} / \\
\mathrm{cm}^{2}\end{array}$ & Power & Microorganisms & Result \\
\hline $\begin{array}{l}\text { Qin et al. } \\
\text { In vitro }\end{array}$ & [34] & $\begin{array}{l}\text { Diode } \\
632\end{array}$ & Toluidine blue & $\begin{array}{c}3,6 \\
12, \\
\text { and } \\
24\end{array}$ & $\begin{array}{l}53,106 \\
159,212\end{array}$ & No info & Periodontal pathogens & $\begin{array}{l}\text { The best therapeutic } \\
\text { was observed in } \\
\text { treatment by } 1 \mathrm{mg} / \\
\mathrm{ml} \text { with } 12 \mathrm{~J} / \mathrm{cm}^{2} \text { at } \\
195 \mathrm{~mW} / \mathrm{cm}^{2} \text { killing the } \\
\text { pathogens }\end{array}$ \\
\hline $\begin{array}{c}\text { Braun A. et al. } \\
\text { In vivo }\end{array}$ & [13] & $\begin{array}{l}\text { Diode } \\
660\end{array}$ & $\begin{array}{l}\text { Phenothiazine } \\
\text { chloride }\end{array}$ & $\begin{array}{l}\text { No } \\
\text { info }\end{array}$ & No info & $100 \mathrm{~mW}$ & Chronic periodontitis & $\begin{array}{l}\text { Positive effect on } \\
\text { treatment outcomes }\end{array}$ \\
\hline $\begin{array}{l}\text { Berakdar et al. } \\
\text { Christodoulides } \\
\text { et al. } \\
\text { Ge et al. } \\
\text { Lulic et al. } \\
\text { In vivo }\end{array}$ & $\begin{array}{l}{[14]} \\
{[15]} \\
{[16]} \\
{[17]}\end{array}$ & $\begin{array}{l}\text { Diode } \\
670\end{array}$ & $\begin{array}{l}\text { Methylen blue } \\
\text { HELBOA Blue } \\
\text { Methylen blue } \\
\text { HELBOA Blue }\end{array}$ & $\begin{array}{l}\text { No } \\
\text { info } \\
21\end{array}$ & $\begin{array}{c}\text { No info } \\
\text { No info } \\
\text { No info } \\
75\end{array}$ & $\begin{array}{l}150 \mathrm{~mW} \\
75 \mathrm{~mW} \\
140 \mathrm{~mW} \\
\text { No info }\end{array}$ & $\begin{array}{l}\text { T. forsythensis. } \\
\text { Terponema denticola. } \\
\text { Fusobacterium } \\
\text { uncleatum. } \\
\text { Eikenella corrodens }\end{array}$ & $\begin{array}{l}\text { Reduction In bleeding } \\
\text { scores } \\
\text { And pocket depth }\end{array}$ \\
\hline $\begin{array}{l}\text { Chui C. et al. } \\
\text { In vitro }\end{array}$ & [38] & $\begin{array}{l}\text { Blue LED } \\
425-470 \\
\text { Red LED } \\
625-635\end{array}$ & $\begin{array}{l}\text { Toluidine blue } \\
\text { Erythrosine } \\
\text { Phloxine } \\
\text { Rose bengal }\end{array}$ & $\begin{array}{l}30, \\
60, \\
90 \text { for } \\
\text { BL } \\
\text { and } \\
30,60 \\
\text { for } \\
\text { RL }\end{array}$ & $\begin{array}{l}1.0 \text { and } \\
0.5\end{array}$ & $\begin{array}{l}365 \text { for } \\
\text { BL and } \\
185 \text { for } \\
\text { RL }\end{array}$ & $\begin{array}{l}\text { Prophyromonas } \\
\text { gingivalis }\end{array}$ & $\begin{array}{l}\text { A log reduction was } \\
\text { obtained after } 30 \mathrm{~J} / \\
\mathrm{cm}^{2} \mathrm{RL} \text { with TB and BL } \\
\text { with RB in periodontal } \\
\text { therapy }\end{array}$ \\
\hline $\begin{array}{c}\text { Braham et al. } \\
\text { In vitro }\end{array}$ & [18] & $\begin{array}{l}\text { Diode } \\
670\end{array}$ & Methylen blue & $\begin{array}{l}\text { No } \\
\text { info }\end{array}$ & No info & $150 \mathrm{~mW}$ & $\begin{array}{l}\text { Porphyromonas } \\
\text { gingivalis }\end{array}$ & $\begin{array}{l}\text { Increasing bacterial } \\
\text { killing } p \text {. gingivalis }\end{array}$ \\
\hline $\begin{array}{c}\text { Al-Zahrani et al. } \\
\text { In vivo }\end{array}$ & [24] & $\begin{array}{l}\text { Diode } \\
670\end{array}$ & Methylen blue & $\begin{array}{l}\text { No } \\
\text { info }\end{array}$ & No info & No info & $\begin{array}{l}\text { Diabetes and } \\
\text { periodontitis }\end{array}$ & No effect \\
\hline
\end{tabular}




\begin{tabular}{|c|c|c|c|c|c|c|c|c|}
\hline $\begin{array}{l}\text { Polansky et al. } \\
\text { In vivo }\end{array}$ & [25] & Diode 680 & HELBOA Blue & $\begin{array}{l}\text { No } \\
\text { info }\end{array}$ & No info & $75 \mathrm{~mW}$ & $\begin{array}{c}\text { P. gingivalis } \\
\text { T. forsythiaT.denticola. }\end{array}$ & $\begin{array}{l}\text { P. gingivalis was } \\
\text { reduced significantly, } \\
\text { but no significant } \\
\text { reduction of } T \text {. } \\
\text { Forsythia and } \\
\text { T.denticola. was found }\end{array}$ \\
\hline $\begin{array}{l}\text { Rűhling et al. } \\
\text { In vivo }\end{array}$ & [26] & Diode 635 & Tolonium chloride & $\begin{array}{l}\text { No } \\
\text { info }\end{array}$ & No info & $100 \mathrm{~mW}$ & Periodontal pocket & $\begin{array}{l}\text { Microbial counts were } \\
\text { significantly reduced } \\
\text { about 30\% to } 40 \% \\
\text { immediately }\end{array}$ \\
\hline $\begin{array}{l}\text { Sigusch et al. } \\
\text { In vivo }\end{array}$ & [19] & Diode 660 & $\begin{array}{l}\text { Phenothiayine } \\
\text { chloride }\end{array}$ & $\begin{array}{l}\text { No } \\
\text { info }\end{array}$ & 60 & No info & F. nucleatum & $\begin{array}{c}\text { F. nucleatum DNA } \\
\text { concentration } \\
\text { Reduced }\end{array}$ \\
\hline $\begin{array}{l}\text { F. D. L. Mattiello } \\
\text { et al. } \\
\text { In vitro }\end{array}$ & [20] & Diode 660 & Toluidine blue & 10 & No info & $40 \mathrm{~mW}$ & $\begin{array}{l}\text { Actinomycetemcomitans } \\
\text { (A.a) Sterptococcus } \\
\text { sanguinis (S.s). }\end{array}$ & $\begin{array}{l}\text { Reduction in number in } \\
\text { Dye/laser group }\end{array}$ \\
\hline $\begin{array}{l}\text { Lui et al. } \\
\text { In vivo }\end{array}$ & [27] & $\begin{array}{l}\text { Diode } \\
940\end{array}$ & Methylene blue & 4 & No info & $1.0 \mathrm{~W}$ & $\begin{array}{l}\text { Nonsurgical treatment of } \\
\text { chronic periodontitis }\end{array}$ & $\begin{array}{l}\text { Greater reduction in } \\
\text { gingival cervical fluid at } \\
1 \mathrm{WK} \text {. And bleeding on } \\
\text { probing depth at } 1 \mathrm{Mo}\end{array}$ \\
\hline $\begin{array}{l}\text { Giannopoulou } \\
\text { et al. } \\
\text { In vivo }\end{array}$ & [46] & $\begin{array}{l}\text { Diode } \\
660 \\
\text { Diode } \\
810\end{array}$ & $\begin{array}{l}\text { Phenothiayine } \\
\text { chloride }\end{array}$ & $\begin{array}{l}\text { No } \\
\text { info }\end{array}$ & $\begin{array}{l}\text { No info } \\
\text { No info }\end{array}$ & $\begin{array}{c}100 \mathrm{~mW} \\
1 \mathrm{~W}\end{array}$ & Residual pockets & $\begin{array}{l}\text { There was no } \\
\text { evidence for a } \\
\text { specific DSL- or PDT- } \\
\text { enhanced expression } \\
\text { of inflammatory } \\
\text { mediators }\end{array}$ \\
\hline $\begin{array}{l}\text { Filho et al. } \\
\text { In vivo }\end{array}$ & [30] & $\begin{array}{l}\text { Diode } \\
660\end{array}$ & Methylene blue & 57.14 & 0.428 & $0.03 \mathrm{~W}$ & $\begin{array}{l}\text { Periodontitis in HIV } \\
\text { patient }\end{array}$ & $\begin{array}{l}\text { PDT therapy used } \\
\text { as an adjunct to } \\
\text { SRP could promote } \\
\text { additional benefits } \\
\text { in the treatment } \\
\text { of HIV-associated } \\
\text { periodontitis }\end{array}$ \\
\hline $\begin{array}{l}\text { Dilsiz et al. } \\
\text { In vivo }\end{array}$ & [28] & $\begin{array}{l}\text { KTP } \\
532\end{array}$ & Methylene blue & 11.7 & No info & $\begin{array}{c}0.8 \mathrm{~W} \\
100 \mathrm{~mW}\end{array}$ & Chronic periodontitis & $\begin{array}{l}\text { Deep pockets can be } \\
\text { improved by using } \\
\text { adjunctive KTP laser }\end{array}$ \\
\hline $\begin{array}{c}\text { Campos et al. } \\
\text { In vivo }\end{array}$ & [22] & $\begin{array}{l}\text { Diode } \\
660\end{array}$ & Methylene blue & 129 & No info & $60 \mathrm{~mW}$ & $\begin{array}{l}\text { Prophyromonas } \\
\text { gingivalis } \\
\text { T. Forsythia }\end{array}$ & $\begin{array}{c}\text { The reduction in } P . \\
\text { gngivalis and } \\
\text { T. Forsythia }\end{array}$ \\
\hline $\begin{array}{l}\text { Voos et al. } \\
\text { In vitro }\end{array}$ & [23] & $\begin{array}{l}\text { Diode } \\
532\end{array}$ & Safranine 0 & $\begin{array}{l}5,12, \\
\text { and } \\
20\end{array}$ & No info & $0.5 \mathrm{~W}$ & $\begin{array}{l}\text { F. nucleatum } \\
\text { P. gingivali }\end{array}$ & $\begin{array}{l}\text { A PDT with safranin } \\
\text { o showed a distinct } \\
\text { antibacterial effect } \\
\text { on } F \text {. nucleatum and } P \text {. } \\
\text { gingivalis in } 24 \text {-hour } \\
\text { more than treatment } \\
\text { with } 0.2 \% \text { CHX }\end{array}$ \\
\hline
\end{tabular}




\begin{tabular}{|c|c|c|c|c|c|c|c|c|}
\hline $\begin{array}{l}\text { Macedo et al. } \\
\text { In vitro }\end{array}$ & {$[31]$} & Diode 660 & $\begin{array}{l}\text { Phenothiazine } \\
\text { chloride }\end{array}$ & $\begin{array}{l}2.79 \\
\text { per } \\
\text { site } \\
\text { and } \\
16.72 \\
\text { per } \\
\text { tooth }\end{array}$ & 28 & $60 \mathrm{~mW}$ & Periodontal disease & $\begin{array}{l}\text { No effect. } \\
\text { But was able to } \\
\text { promote a significant } \\
\text { reduction in glycated } \\
\text { hemoglobin levels } \\
\text { (HbA1c) }\end{array}$ \\
\hline $\begin{array}{l}\text { Queiroz et al. } \\
\text { In vitro }\end{array}$ & [32] & $\begin{array}{l}\text { Diode } \\
660\end{array}$ & $\begin{array}{l}\text { Phenothiazine } \\
\text { chloride }\end{array}$ & $\begin{array}{l}2.79 \\
\text { per } \\
\text { site } \\
\text { and } \\
16.72 \\
\text { per } \\
\text { teeth }\end{array}$ & 28 & $60 \mathrm{~mW}$ & $\begin{array}{l}\text { Smokers with chronic } \\
\text { periodontitis }\end{array}$ & No effect \\
\hline $\begin{array}{c}\text { Skurska et al. } \\
\text { In vitro }\end{array}$ & [29] & $\begin{array}{l}\text { Diode } \\
660\end{array}$ & HELBOA Blue & $\begin{array}{l}\text { No } \\
\text { info }\end{array}$ & No info & No info & $\begin{array}{c}\text { Aggressive periodontitis } \\
\text { (AgP) }\end{array}$ & $\begin{array}{l}\text { Nonsurgical } \\
\text { Periodontal therapy } \\
\text { in conjunction with } \\
\text { adjunctive systemic } \\
\text { administration of } \\
\text { amoxicillin and } \\
\text { metronidazole is more } \\
\text { effective in reducing } \\
\text { GCF MMP-8 levels } \\
\text { compared to the } \\
\text { adjunctive use of PDT }\end{array}$ \\
\hline $\begin{array}{l}\text { Petelin et al. } \\
\text { In vitro }\end{array}$ & [40] & $\begin{array}{l}\text { Diode } \\
660\end{array}$ & $\begin{array}{l}\text { Phenothiazine } \\
\text { chloride }\end{array}$ & $\begin{array}{l}\text { No } \\
\text { info }\end{array}$ & 60 & No info & $\begin{array}{l}\text { Treponema denticola } \\
\text { (TD). Aggregatibacter } \\
\text { actinomycetemcomitans } \\
\text { (AA). Tannerella } \\
\text { forsythia. }\end{array}$ & $\begin{array}{l}\text { Higher reduction of } \\
\text { bleeding on probing } \\
\text { (BOP) at } 3 \text { and } 12 \\
\text { months compared } \\
\text { to US alone or SRP } \\
\text { and reduced after } 6 \\
\text { months Treponema } \\
\text { denticola (TD), and } \\
\text { a greater reduction } \\
\text { of Aggregatibacter } \\
\text { actinomycetemcomitans } \\
\text { (AA), Tannerella } \\
\text { forsythia (TF), and TD } \\
\text { in medium pockets and } \\
\text { of TD in deep pockets }\end{array}$ \\
\hline $\begin{array}{c}\text { Monzavi et al. } \\
\text { In vitro }\end{array}$ & [41] & $\begin{array}{c}810 \\
\text { Diode }\end{array}$ & $\begin{array}{l}\text { Indocyanine green } \\
\text { ICG } \\
\text { Emundo }\end{array}$ & 6 & No info & $200 \mathrm{~mW}$ & Chronic periodontitis & $\begin{array}{l}\text { Reduction in } \\
\text { periodontal pocket } \\
\text { depth }\end{array}$ \\
\hline $\begin{array}{l}\text { Giannellin et al. } \\
\text { In vitro }\end{array}$ & [42] & $\begin{array}{c}635 \\
\text { Diode }\end{array}$ & Methylene blue & 3.8 & 11.6 & $100 \mathrm{~mW}$ & Chronic periodontitis & $\begin{array}{l}\text { Improves healing in } \\
\text { chronic periodontitis } \\
\text { patients }\end{array}$ \\
\hline $\begin{array}{l}\text { Balata et al. } \\
\text { In vitro }\end{array}$ & [43] & $\begin{array}{c}660 \\
\text { Diode }\end{array}$ & Methylene blue & 320 & No info & $100 \mathrm{~mW}$ & Chronic periodontitis & $\begin{array}{l}\text { Improvement in the } \\
\text { treatment of severe } \\
\text { chronic periodontitis }\end{array}$ \\
\hline $\begin{array}{c}\text { Fontana et al. } \\
\text { In vitro }\end{array}$ & [44] & $\begin{array}{c}455 \\
\text { Blue light }\end{array}$ & $\begin{array}{c}\text { Black-pigment } \\
\text { Bacteria }\end{array}$ & 12 & 50 & No info & The eight species & $\begin{array}{c}\text { Reduction in relative } \\
\text { abundances of the eight } \\
\text { bacteria }\end{array}$ \\
\hline $\begin{array}{l}\text { Birang et al. } \\
\text { In vitro }\end{array}$ & [35] & $\begin{array}{l}\text { Diode } \\
810\end{array}$ & Emundo & $\begin{array}{l}\text { No } \\
\text { info }\end{array}$ & 0.5 & No info & Chronic periodontitis & $\begin{array}{l}\text { Benefits in the } \\
\text { treatment of chronic } \\
\text { periodontitis }\end{array}$ \\
\hline
\end{tabular}




\begin{tabular}{|c|c|c|c|c|c|c|c|c|}
\hline $\begin{array}{l}\text { Qiao et al. } \\
\text { In vitro }\end{array}$ & [45] & $\begin{array}{r}675 \\
\text { Diode }\end{array}$ & Methylene blue & 19.7 & 329 & $280 \mathrm{~mW}$ & $\begin{array}{l}\text { Human periodontal } \\
\text { ligament cell and human } \\
\text { gingival fibroblasts }\end{array}$ & $\begin{array}{l}\text { Stimulated } \\
\text { proliferation }\end{array}$ \\
\hline $\begin{array}{l}\text { Campanile et al. } \\
\text { In vitro }\end{array}$ & [46] & $\begin{array}{c}670 \\
\text { Diode }\end{array}$ & Methylene blue & $\begin{array}{l}\text { No } \\
\text { info }\end{array}$ & No info & $280 \mathrm{~mW}$ & Periodontitis & $\begin{array}{c}\text { Single or double } \\
\text { episodes of PDT had } \\
\text { some additional } \\
\text { benefit over ultrasonic } \\
\text { instrumentation alone }\end{array}$ \\
\hline $\begin{array}{l}\text { Bassir et al. } \\
\text { In vitro }\end{array}$ & [47] & $\begin{array}{c}\text { 625-635 } \\
\text { Diode }\end{array}$ & Toluidine blue & $\begin{array}{l}\text { No } \\
\text { info }\end{array}$ & 2000 & No info & Chronic periodontitis & $\begin{array}{l}\text { Did not have additional } \\
\text { effects on clinical } \\
\text { parameters }\end{array}$ \\
\hline $\begin{array}{l}\text { Betsy et al. } \\
\text { In vitro }\end{array}$ & [48] & $\begin{array}{r}655 \\
\text { Diode }\end{array}$ & Methylene blue & $\begin{array}{l}\text { No } \\
\text { info }\end{array}$ & 60 & No info & Chronic periodontitis & $\begin{array}{l}\text { Acts as a beneficial } \\
\text { adjunct to SRP }\end{array}$ \\
\hline $\begin{array}{l}\text { Boehm et al. } \\
\text { In vitro }\end{array}$ & [36] & $\begin{array}{l}\text { Diode } \\
810\end{array}$ & $\begin{array}{l}\text { Indocyanine green } \\
\text { ICG } \\
\text { Emundo }\end{array}$ & $\begin{array}{l}\text { No } \\
\text { info }\end{array}$ & $10-80$ & $0.5 \mathrm{~W}$ & Periodontal pockets. & Reduction of bacterial \\
\hline $\begin{array}{c}\text { Andersen et al. } \\
\text { In vitro }\end{array}$ & [8] & $\begin{array}{c}670 \\
\text { Diode }\end{array}$ & Methylene blue & $10-20$ & No info & $150 \mathrm{~mW}$ & Nonsurgical periodontal & $\begin{array}{l}\text { Significant } \\
\text { improvements of } \\
\text { the investigated } \\
\text { parameters }\end{array}$ \\
\hline $\begin{array}{l}\text { Seguier et al. } \\
\text { In vitro }\end{array}$ & [50] & $\begin{array}{l}\text { Diode } \\
670\end{array}$ & Phthalocyanine & 121.7 & 0.5 & No info & $\begin{array}{l}\text { Chronic human } \\
\text { periodontitis }\end{array}$ & Reduction of bacterial \\
\hline $\begin{array}{l}\text { Correa et al. } \\
\text { In vitro }\end{array}$ & [51] & $\begin{array}{r}660 \\
\text { Diode }\end{array}$ & Methylene blue & 129 & No info & $60 \mathrm{~mW}$ & Unresponsive pockets & $\begin{array}{l}\text { Improvement in clinical } \\
\text { parameters in treating } \\
\text { residual pockets }\end{array}$ \\
\hline $\begin{array}{l}\text { Moreira et al. } \\
\text { In vitro }\end{array}$ & [52] & $\begin{array}{r}670 \\
\text { Diode }\end{array}$ & $\begin{array}{l}\text { HELBO } \\
\text { Blue }\end{array}$ & 2.49 & 0.25 & No info & Aggressive periodontitis & $\begin{array}{l}\text { Promotes additional } \\
\text { clinical, microbiologic, } \\
\text { and immunologic } \\
\text { benefits in the } \\
\text { treatment of deep } \\
\text { periodontal pockets in } \\
\text { single-rooted teeth in } \\
\text { patients with AgP }\end{array}$ \\
\hline $\begin{array}{l}\text { Freitas et al. } \\
\quad \text { In vitro }\end{array}$ & [53] & $\begin{array}{c}660 \\
\text { Diode }\end{array}$ & Methylene blue & 20 & 100 & N0 info & $\begin{array}{l}\text { Human dental plaque } \\
\text { bacteria }\end{array}$ & $\begin{array}{c}\text { Promising adjunct } \\
\text { in antimicrobial } \\
\text { periodontal treatment }\end{array}$ \\
\hline
\end{tabular}

\section{Discussion}

Several in vitro and in vivo human studies have demonstrated that microorganisms related to periodontal disease such as Porphyromonas gingivalis, Aggregatibacter actinomycetemcomitans (previously Actinobacillus actinomycetemcomitans), Fusobacterium nucleatum, Prevotella intermedia and Streptococcus sanguis are significantly reduced in number by a PDT with diode laser $660 \mathrm{~nm}$ and $670 \mathrm{~nm}$ under different environmental conditions (in vitro and in vivo human study) [13-22]. However, it should be kept in mind that a recent study demonstrated addition clinical benefits of subgingival ultrasonic scaling are achieved by repeating (three times) PDT in [23].
Within the limitation of the study [24] no extra benefit of PDT of diode laser $670 \mathrm{~nm}$ on clinical periodontal parameters was found in patient with diabetes. This study cannot be reliably upon because in addition to the small number of cases, it also lacks the detail that is required by the readers of the laser parameters. One clinical trial evaluating the application of one cycle of the PDT laser diode $680 \mathrm{~nm}$ was not effective as an adjunct to ultrasonic gums, there was no further reduction in the depth of the sinus and bleeding on the probe [25]. The lack of a laser effect-in our opinion-may be attributed to exposure time about 1 minute very short. In addition, older people have a slower metabolic process than children, which negatively affects the healing process. More recently, in vivo studies 
have shown a decrease by reduction of periodontal signs of redness, periodontal pocket, gingival cervical fluid and bleeding on probing after aPDT for the treatment of periodontitis [26-29].

Immunosuppression caused by HIV is associated with different forms of periodontal disease as well as the exacerbation of a preexisting periodontitis. One study [30] demonstrated that clinical outcomes following the non-surgical periodontal treatment of patients with HIV-associated chronic periodontitis were improved by using the adjective PDT diode laser $660 \mathrm{~nm}$ procedure. Moreover, this diode laser reduced P. Gingivalis, T. Forsythia, and A. Actinomycetemcomitans. In 2 present clinical studies [31,32], aPDT was tested as an adjunct for the treatment of chronic periodontitis in patient with diabetes type 2 and in smoker's patient. These studies demonstrated clinical improvement after aPDT with (diode laser $660 \mathrm{~nm}$ and $2.79 \mathrm{~J} / \mathrm{cm}^{2}$ ) as adjunctive therapy after SRP+aPDT was used, but they were similar to SPR group, and showed similar reductions in bleeding on probing after nonsurgical periodontal treatment in patients with diabetes. However, it is important to emphasize that poorly controlled diabetes can promote vascular alteration [31] and other metabolic alterations that can be involved in the appearance of symptoms such as gingival bleeding. Thus, it is difficult to compare diabetic patients with healthy patients and the effect of aPDT on the reduction of gingival bleeding. Furthermore, it is well accepted that smoking alters the host response, including vascular function, neutrophil/monocyte activities, adhesion molecule expression, antibody production, as well as the release of cytokine and inflammatory [33]. Therefore, the negative influence of smoking, which impairs normal host responses, might have made it difficult to verify significant differences in IL-1 $\beta$ and MMP8 concentration.

One study [34] has indicated that it is possible to kill bacteria in supra gingival plaque scrapings by using topically applied TB and $635 \mathrm{~nm}$ red light from a diode laser. The effect of TB-mediated PDT in treating PP greatly depends on photosensitizer concentration, light intensity, and light energy dose. Where they found the most effective combination is that of $1 \mathrm{mg} / \mathrm{ml} \mathrm{TB}$ with $12 \mathrm{~J} / \mathrm{cm}^{2}$ light at $212 \mathrm{~mW} / \mathrm{cm} 2$, which produced a $47-99 \%$ killing rate for different patients. Birang et al. The LLLT of the low-level diode, associated with the traditional SRP was more effective in reducing PPD than that achieved by PDT with SRP or SRP alone. This result is inconsistent with Boehm et al. [36] whose laboratory studies showed that ICG therapy with an $810 \mathrm{~nm}$ diode laser may be useful as a dynamic optical assistant to reduce bacterial load in gingival pockets. The important point to consider when interpreting the

Table 2: Articles listed were chosen based on the positive results. clinical and bacterial results obtained by PDT is the effect of the same optical sensitizers. This means ICG act as a light agent under these conditions, but also it has bactericidal effect by efficiently absorbing the laser energy within the cells and denaturing bacterial proteins.

The difference in the antimicrobial/growth-inhibiting effect between BL and RL may be a result of the difference in the wavelength property of both lights. On BL irradiation, it has been speculated that endogenous porphyrin produced by bacteria is excited, leading to a Photodynamic reaction through singlet oxygen production, resulting in an antimicrobial effect [37]. In contrast, one in vitro study [38] used a high-power BL, expecting a higher antimicrobial effect as well as a shorter irradiation time, which are important in clinical practice. The antimicrobial effect of highpower BL on P. Gingivalis [38] was detected after short time periods of irradiation of 60 and 90 s. Moreover, a-PDT using a combination of BL and RB shows promise as a new technical modality for bacterial elimination in periodontal therapy.

Chlorhexidine ( $\mathrm{CHX}$ ) is a cationic agent that binds to the bacterial cell wall and leads to an increase of permeability. For a sufficient effect the CHX concentration needs to be strong enough to imbalance the osmotic pressure of the bacterial cell [39]. Voss et al. [23] showed that the gram-negative bacteria were more sensitive to treatment with CHX. In contrast, a PDT proved to be more efficient on the gram-positive species. However, the main antibacterial agent of a PDT is singlet oxygen, which is produced by the Photodynamic reaction and leads to a massive destruction, Photodynamic treatment with safranine 0 was significantly more efficient than subjection to $0.2 \%$ CHX, But, compared to the action of CHX and a PDT with safranine 0 , a PDT with safranine 0 were still more efficient in reducing bacterial growth. This method is more effective than treatment with $0.2 \% \mathrm{CH}$ [40-46].

\section{Conclusion}

The in vivo and in vitro studies present in the literature, indicate that a PDT may potentially become successful. In addition, infectious procedure associated with conventional therapy can be successful in the management of periodontal disease and Photodynamic therapy has the advantage of reduced treatment time and the need for anesthesia, which destroys bacteria in a very short period of time without developing resistance to bacteria [47-53]. From the reviewed articles, we could conclude some suitable parameters for PDT as an adjunctive therapy in periodontal disease treatment. Those articles listed in Table 2 were chosen based on the positive results they demonstrated.

\begin{tabular}{|c|c|c|c|c|c|c|}
\hline $\begin{array}{c}\text { Laser and } \\
\text { Wavelength (nm) }\end{array}$ & Photosensitization & $\begin{array}{c}\text { Dose } \\
\mathbf{J} / \mathbf{c m} \text { 2) }\end{array}$ & $\begin{array}{c}\text { Power Density } \\
\mathbf{m W / \mathbf { c m } 2}\end{array}$ & Power & Place of Influence & Result \\
\hline Diode 660 & Methylene blue & 57.14 & 0.428 & $0.03 \mathrm{~mW}$ & $\begin{array}{c}\text { Periodontitis in } \\
\text { HIV patient } \\
\text { as an adjunct to } \\
\text { SRP could promote } \\
\text { additional benefits } \\
\text { in the treatment } \\
\text { of HIV-associated } \\
\text { periodontitis }\end{array}$ \\
\hline
\end{tabular}




\begin{tabular}{|c|c|c|c|c|c|c|}
\hline Diode 635 & Methylene blue & 3.8 & 11.6 & $100 \mathrm{~mW}$ & $\begin{array}{c}\text { Chronic } \\
\text { periodontitis }\end{array}$ & $\begin{array}{l}\text { Improves healing } \\
\text { in chronic } \\
\text { periodontitis } \\
\text { patients }\end{array}$ \\
\hline Diode 810 & $\begin{array}{l}\text { Indocyanine green ICG } \\
\text { Emundo }\end{array}$ & 6 & No info & $200 \mathrm{~mW}$ & $\begin{array}{l}\text { Chronic } \\
\text { periodontitis }\end{array}$ & $\begin{array}{c}\text { Reduction in } \\
\text { periodontal pocket } \\
\text { depth }\end{array}$ \\
\hline
\end{tabular}

\section{References}

1. Saini R, Marawar PP, Shete S, Saini S (2009) Periodontitis, a true infection. J Glob Infect Dis 1(2): 149-150.

2. Palomo L, Palomo JM, Bissada NF (2008) Salient periodontal issues for the modern biologic orthodontist. In Seminars in Orthodontics 14(4): 229-245.

3. (2013) Periodontal (gum) disease: causes, symptoms, and treatments National Institutes of Dental and craniofacial Research, USA, 13: 1142.

4. Lockhart PB, Bolger AF, Papapanou PN, Osinbowale O, Trevisan M (2012) Periodontal disease and atherosclerotic vascular disease: does the evidence support an independent association? a scientific statement from the American heart association. Circulation 125(20): 2520-2544.

5. Michele LD, Margaret MW (2009) Procedures manual to accompany dental hygiene ( $1^{\text {st }}$ edn), Saunders, USA, p. 424.

6. Konopka K, Goslinski T (2007) Photodynamic therapy in dentistry. J Dent Res 86(8): 694-707.

7. Carvalho AS, Napimoga MH, Coelho-Campos J, Silva-Filho VJ, Thedei G (2011) Photodynamic therapy reduces bone resorption and decreases inflammatory response in an experimental rat periodontal disease model. Photomed Laser Surg 29(11): 735-740.

8. Andersen R, Loebel N, Hammond D, Wilson M (2007) Treatment of periodontal disease by photodisinfection compared to scaling and root planing. J Clin Dent 18(2): 34-38.

9. Harris F, Chatfield LK, Phoenix DA (2005) Phenothiazinium based photosensitisers-photodynamic agents with a multiplicity of cellular targets and clinical applications. Current Drug Targets 6(5): 615-627.

10. Juarranz A, Jaén P, Sanz-Rodríguez F, Cuevas J, González S (2008) Photodynamic therapy of cancer. Basic principles and applications. Clin Transl Oncol 10(3): 148-154.

11. Dolmans DE, Fukumura D, Jain RK (2003) Photodynamic therapy for cancer. Nat Rev Cancer 3(5): 380-387.

12.Sgolastra F, Petrucci A, Gatto R, Marzo G, Monaco A (2013) Photodynamic therapy in the treatment of chronic periodontitis: a systematic review and meta-analysis. Lasers Med Sci 28(2): 669-682.

13. Braun A, Dehn C, Krause F, Jepsen S (2008) Short-term clinical effects of adjunctive antimicrobial photodynamic therapy in periodontal treatment: a randomized clinical trial. J Clin Periodontol 35(10): 877884.

14. Berakdar M, Callaway A, Eddin MF, Ross A, Willershausen B (2012) Comparison between scaling-root-planing (SRP) and SRP/ photodynamic therapy: six-month study. Head Face Med 8: 12.

15. Christodoulides N, Nikolidakis D, Chondros P, Becker J, Schwarz F, et al. (2008) Photodynamic therapy as an adjunct to non-surgical periodontal treatment: a randomized, controlled clinical trial. J Periodontol 79(9): 1638-1644.

16. Ge L, Shu R, Li Y, Li C, Luo L (2011) Adjunctive effect of photodynamic therapy to scaling and root planing in the treatment of chronic periodontitis. Photomed Laser Surg 29(1): 33-37.
17. Lulic M, Leiggener Görög I, Salvi GE, Ramseier CA, Mattheos N (2009) One-year outcomes of repeated adjunctive photodynamic therapy during periodontal maintenance: a proof-of-principle randomizedcontrolled clinical trial. J Clin Periodontol 36(8): 661-666.

18. Braham P, Herron C, Street C, Darveau R (2009) Antimicrobial photodynamic therapy may promote periodontal healing through multiple mechanisms. J periodontol 80(11): 1790-1798.

19. Sigusch BW, Engelbrecht M, Völpel A, Holletschke A, Pfister W (2010) Full-mouth antimicrobial photodynamic therapy in Fusobacterium nucleatum-infected periodontitis patients. J periodontol 81(7): 975-981.

20. Mattiello FD, Coelho AA, Martins OP, Mattiello RD, Ferrão Júnior JP (2011) In vitro effect of photodynamic therapy on aggregatibacter actinomycetemcomitans and streptococcus sanguinis. Braz Dent J 22(5): 398-403.

21. Giannopoulou C, Cappuyns I, Cancela J, Cionca N, Mombelli A (2012) Effect of photodynamic therapy, diode laser, and deep scaling on cytokine and acute-phase protein levels in gingival crevicular fluid of residual periodontal pockets. J Periodontol 83(8): 1018-1027.

22. Campos GN, Pimentel SP, Ribeiro FV, Casarin RC, Cirano FR (2013) The adjunctive effect of photodynamic therapy for residual pockets in single-rooted teeth: a randomized controlled clinical trial. Lasers Med Sci 28(1): 317-324.

23. Voos AC, Kranz S, Tonndorf-Martini S, Voelpel A, Sigusch H, et al. (2014) Photodynamic antimicrobial effect of safranine $O$ on an ex vivo periodontal biofilm. Lasers Surg Med 46(3): 235-243.

24. Al-Zahrani MS, Bamshmous SO, Alhassani AA, Al-Sherbini MM (2009) Short-term effects of photodynamic therapy on periodontal status and glycemic control of patients with diabetes. J Periodontol 80(10): 15681573.

25. Polansky R, Haas M, Heschl A, Wimmer G (2009) Clinical effectiveness of photodynamic therapy in the treatment of periodontitis. J Clin Periodontol 36(7): 575-580.

26. Rühling A, Fanghänel J, Houshmand M, Kuhr A, Meisel P, et al. (2010) Photodynamic therapy of persistent pockets in maintenance patients-a clinical study. Clin Oral Investig 14(6): 637-644.

27. Lui J, Corbet EF, Jin L (2011) Combined photodynamic and low-level laser therapies as an adjunct to nonsurgical treatment of chronic periodontitis. J Periodontal Res 46(1): 89-96

28. Dilsiz A, Canakci V, Aydin T (2013) Clinical effects of potassiumtitanyl-phosphate laser and photodynamic therapy on outcomes of treatment of chronic periodontitis: a randomized controlled clinical trial. J Periodontol 84(3): 278-286.

29. Skurska A, Dolinska E, Pietruska M, Pietruski JK, Dymicka V, et al. (2015) Effect of nonsurgical periodontal treatment in conjunction with either systemic administration of amoxicillin and metronidazole or additional photodynamic therapy on the concentration of matrix metalloproteinases 8 and 9 in gingival crevicular fluid in patients with aggressive periodontitis. BMC oral health 15: 63.

30. Noro Filho GA, Casarin RC, Casati MZ, Giovani EM (2012) PDT in nonsurgical treatment of periodontitis in HIV patients: A split-mouth, randomized clinical trial. Lasers Surg Med 44(4): 296-302. 
31. Macedo GO, Novaes AB, Souza SL, Taba M, Palioto DB, et al. (2014) Additional effects of aPDT on nonsurgical periodontal treatment with doxycycline in type II diabetes: a randomized, controlled clinical trial. Lasers Med Sci 29(3): 881-886.

32. Queiroz AC, Suaid FA, de Andrade PF, Oliveira FS, Novaes AB (2015) Adjunctive effect of antimicrobial photodynamic therapy to nonsurgical periodontal treatment in smokers: a randomized clinical trial. Lasers Med Sci 30(2): 617-625.

33. Tymkiw KD, Thunell DH, Johnson GK, Joly S, Burnell KK, et al. (2011) Influence of smoking on gingival crevicular fluid cytokines in severe chronic periodontitis. J Clin Periodontol 38(3): 219-228.

34. Qin Y, Luan X, Bi L, He G, Bai X, et al. (2008) Toluidine blue-mediated photoinactivation of periodontal pathogens from supragingival plaques. Lasers Med Sci 23(1): 49-54.

35. Birang R, Shahaboui M, Kiani S, Shadmehr E, Naghsh N (2015) Effect of nonsurgical periodontal treatment combined with diode laser or photodynamic therapy on chronic periodontitis: a randomized controlled split-mouth clinical trial. J Lasers Med Sci 6(3): 112-119.

36. Boehm TK, Ciancio SG (2011) Diode laser activated indocyanine green selectively kills bacteria. J Int Acad Periodontol 13(2): 58-63.

37. Arakane K, Ryu A, Hayashi C, Masunaga T, Shinmoto K, et al (1996) Singlet Oxygen $(1 \Delta \mathrm{g})$ Generation from Coproporphyrin in Propionibacterium acneson Irradiation. Biochemical and biophysical research communications 223(3): 578-582.

38. Chui C, Aoki A, Takeuchi Y, Sasaki Y, Hiratsuka K, et al. (2013) Antimicrobial effect of photodynamic therapy using high-power blue light-emitting diode and red-dye agent on Porphyromonas gingivalis. J Periodontal Res 48(6): 696-705.

39. Varoni E, Tarce M, Lodi G, Carrassi A (2012) Chlorhexidine (CHX) in dentistry: state of the art. Minerva stomatol 61(9): 399-419.

40. Petelin M, Perkič K, Seme K, Gašpirc B (2015) Effect of repeated adjunctive antimicrobial photodynamic therapy on subgingival periodontal pathogens in the treatment of chronic periodontitis. Lasers Med Sci 30(6): 1647-1656

41. Monzavi A, Chinipardaz Z, Mousavi M, Fekrazad R, Moslemi N (2016) Antimicrobial photodynamic therapy using diode laser activated indocyanine green as an adjunct in the treatment of chronic periodontitis: A randomized clinical trial. Photodiagnosis Photodyn Ther 14: 93-97.

42. Giannelli M, Formigli L, Lorenzini L, Bani D (2012) Combined photoablative and photodynamic diode laser therapy as an adjunct to non-surgical periodontal treatment. A randomized split-mouth clinical trial. J Clin Periodontol 39(10): 962-970.
43. Balata ML, Andrade LP, Santos DB, Cavalcanti AN, Tunes UR (2013) Photodynamic therapy associated with full-mouth ultrasonic debridement in the treatment of severe chronic periodontitis: a randomized-controlled clinical trial. J Appl Oral Sci 21(2): 208-214.

44. Fontana CR, Song X, Polymeri A, Goodson JM, Wang X, et al. (2015) The effect of blue light on periodontal biofilm growth in vitro. Lasers Med Sci 30(8): 2077-2086.

45. Qiao J, Wang S, Wen Y, Jia H (2014) Photodynamic effects on human periodontal-related cells in vitro. Photodiagnosis Photodyn Ther 11(3): 290-299.

46. Campanile VSM, Giannopoulou C, Campanile G, Cancela JA, Mombelli A (2015) Single or repeated antimicrobial photodynamic therapy as adjunct to ultrasonic debridement in residual periodontal pockets: clinical, microbiological, and local biological effects. Lasers Med Sci 30(1): 27-34.

47. Bassir SH, Moslemi N, Jamali R, Mashmouly S, Fekrazad R, et al. (2013) Photoactivated disinfection using light-emitting diode as an adjunct in the management of chronic periodontitis: a pilot double-blind splitmouth randomized clinical trial. J Clin Periodontol 40(1): 65-72.

48. Betsy J, Prasanth CS, Baiju KV, Prasanthila J, Subhash N (2014) Efficacy of antimicrobial photodynamic therapy in the management of chronic periodontitis: a randomized controlled clinical trial. J Clin Periodontol 41(6): 573-581.

49. Andersen R, Loebel N, Hammond D, Wilson M (2007) Treatment of periodontal disease by photo disinfection compared to scaling and root planing. J Clin Dent 18(2): 34-38.

50. Séguier S, Souza SL, Sverzut AC, Simioni AR, Primo FL (2010) Impact of photodynamic therapy on inflammatory cells during human chronic periodontitis. J Photochem Photobiol B 101(3): 348-354.

51. Corrêa MG, Oliveira DH, Saraceni CH, Ribeiro FV, Pimentel SP (2015) Short-term microbiological effects of photodynamic therapy in nonsurgical periodontal treatment of residual pockets: A split-mouth RCT. Lasers Surg Med 48(10): 944-950.

52. Moreira AL, Novaes AB, Grisi MF, Taba M, Souza SL (2015) Antimicrobial photodynamic therapy as an adjunct to non-surgical treatment of aggressive periodontitis: a split-mouth randomized controlled trial. J Periodontol 86(3): 376-386.

53. Freitas LM, Calixto GM, Chorilli M, Giusti JS, Bagnato VS (2016) Polymeric nanoparticle-based photodynamic therapy for chronic periodontitis in vivo. Int J Mol Sci 17(5): 769.
Creative Commons Attribution 4.0 International License

For possible submissions Click Here

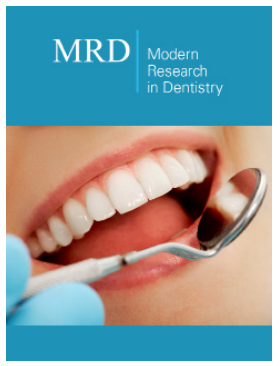

Modern Research in Dentistry

\section{Benefits of Publishing with us}

- High-level peer review and editorial services

- Freely accessible online immediately upon publication

- Authors retain the copyright to their work

- Licensing it under a Creative Commons license

- Visibility through different online platforms 